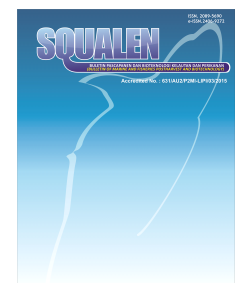

\title{
Screening of Marine-Derived Fungi Extracts as Antioxidant, Tyrosinase Inhibitor, and Antiglycation
}

\author{
Muhammad Nursid', Endar Marraskuranto1, Dilaika Septorini², and Irmanida Batubara ${ }^{2}$ \\ ${ }^{1}$ Research and Development Center for Marine and Fisheries Product Processing and Biotechnology, \\ Jalan KS. Tubun Petamburan VI, Slipi, Jakarta Pusat 10260, Indonesia \\ 2Department of Chemistry, Bogor Agricultural University, Kampus IPB Dramaga Bogor Indonesia \\ Article history: \\ Received: 28 November 2018; Revised: 6 January 2019; Accepted: 7 May 2019
}

\begin{abstract}
Marine-derived fungi are of great interest as new promising sources of bioactive secondary metabolites. The aim of this study was to determine the antioxidant activity, tyrosinase inhibitor and antiglycation of marine-derrived fungi collected from Kepulauan Seribu Marine National Park, Indonesia. Antioxidant screening was determined using the 1,1-diphenyl-2-picryl hydrazyl (DPPH) method. The tyrosinase inhibitor was screened using L-tyrosine substrate, while the antiglycation test was determined by the ability to inhibit the formation of advanced glycation end products (AGEs). A total of 28 marine fungi isolates had been screened for their activities. Mycelium extract of MFP 271 had the best antioxidant activity with the $\mathrm{IC}_{50}$ of $287.25 \pm 50 \mu \mathrm{g} / \mathrm{mL}$. Mycelium extract of MFP 277 had the best tyrosinase inhibitory activity with the $\mathrm{IC}_{50}$ of $586.42 \mu \mathrm{g} / \mathrm{mL}$. The MFP 274-broth extract had the highest antiglycation activity with the $\mathrm{IC}_{50}$ value of $298.57 \mu \mathrm{g} / \mathrm{mL}$. Based on the screening, the crude extracts were considered weak as antioxidant, but tyrosinase inhibitor and antiglycation activity of MFP 277 and MFP 274 are needed to investigate in depth activities.
\end{abstract}

Keywords: antiglycation, antioxidant, tyrosinase inhibitor, marine-derived fungi

\section{Introduction}

Aging is a physiological process that occurs in all living things that includes all organs including the skin. The skin is the outer body tissue that directly shows the aging process. Skin aging occurs due to the presence of free radicals and advanced glycation end (AGEs) products in the body which are the end products of protein glycation reactions (Povichit, Phrutivorapongkul, Suttaji, Chaiyasut, \& Leelapornpisid, 2010). In skin aging process, AGEs interact with collagen and then form helical bonds that cause skin aging, such as the appearance of wrinkles and reduced skin elasticity (Ichihashi, Yagi, Nomoto \& Yonei, 2011). Bad environment and lifestyle such as extended exposure time to pollution, ultraviolet light, and sun can accelerate the skin aging process because it can increase free radicals and oxidative stress. The use of antiaging products is increasingly prevalent in the community in an effort to prevent skin damage and maintain its appearance. Antiaging agents work by inhibiting the formation of AGEs (Ndlovu, Gerda, Malefa, Werner \& Vanessa, 2013).
In addition to aging, excessive production of melanin or skin browning is also a problem. Melanin is responsible for human skin color. Tyrosinase is known as an copper-containing enzyme and plays a role in melanin pigment formation. In this process, it often produces reactive oxygen species (ROS) which can increase melanin pigment formation. Tyrosinase inhibitors are widely used in dermatological treatments or in cosmetics for skin whitening by inhibiting the enzymatic process of melanin formation (Chang, 2012).

Research on tyrosinase inhibitors and antiaging compounds from native Indonesian plants has been carried out, including leaves of the family Zingiberaceae (Zahra, Kartika, Batubara, Darusman \& Maddu, 2015), Protium javanicum leaves (Batubara \& Adfa, 2013), and several medicinal plants (Fathurrahman, 2015). Natural ingredients as antiaging and tyrosinase inhibitors are still being explored due to their safety against synthetic chemicals. In addition to plants, endophytic microbes also have the potential as antiaging and tyrosinase inhibitors, one of which

${ }^{*}$ Corresponding author.

E-mail: muhammad.nursid@kkp.go.id 
is fungi. Endophytic fungi can produce various secondary metabolites, both in structure and function (Kumala \& Fitri, 2008).

Marine environment is a complex ecosystem as well as a habitat for microbes including fungi. Marine derived fungi attracts attention as a source of bioactive compounds. Since marine live organisms are biologically competitive environment with unique conditions of $\mathrm{pH}$, temperature, pressure, oxygen, light, nutrients, and salinity, the chemical diversity of the secondary metabolites of marine fungi are considerably high (Wu, Wu, Sun \& Li, 2012; Hong et al., 2015). Research on antiglycation and tyrosinase inhibitors derived from fungi extract has not been widely carried out. Antibacterial and antioxidants activity derived from marine microbes are quite high. Reported microbes associated with Stylotella sp. has antibacterial activity with the formation of clear zones in some pathogenic bacteria and antioxidants with an antioxidant capacity of $1,610 \mu \mathrm{mol}$ trolox $/ \mathrm{g}$ extract (Yoghiapiscessa, Batubara, \& Wahyudi, 2016). In addition, Utami (2014) reported that marine microbes associated with sponges has antioxidant capacity of $649.92 \mu \mathrm{mol}$ trolox/g extract. Research related to antioxidants and tyrosinase inhibitors from marine fungi, for example, was investigated by $\mathrm{Li}, \mathrm{Li}, \mathrm{Xu}, \mathrm{Li}$ and Wang (2016), Dewi, Tachibana, Itoh and llyas (2012), and El-Hady, Aziz, Shaker and El-Shahid (2014). Considering the high diversity of marine fungi in Indonesia, research to explore the potential of marine fungi as antioxidants, tyrosinase inhibitor, and anti-glycation needs to be conducted. The purpose of this study was to determine antioxidant activity, tyrosinase inhibitor, and antiglycation of marine fungi from the Kepulauan Seribu Marine National Park, Jakarta, Indonesia.

\section{Materials and Methods}

\subsection{Fungi Material}

Fungi used in this research were obtained from Research Center for Marine and Fisheries Product Processing and Biotechnology (RCMFPPB) Culture Collection. These fungi were isolated from the surface of marine invertebrate which had been collected from Kepulauan Seribu Marine National Park.

\subsection{Fungi Cultivation}

Cultivation of fungi was carried out according to Kjer, Debbab, Aly and Proksch (2010) with a slight modification. Sterile malt extract agar (MEA) medium was poured into petri dishes and allowed to solidify. Fungi isolates from deep freezer $\left(-73^{\circ} \mathrm{C}\right)$ were thawed, then inoculated over the MEA medium. Fungi spores were then incubated at $28-29{ }^{\circ} \mathrm{C}$ for 7 days. The growing fungi were then inoculated into an Erlenmeyer flask containing $100 \mathrm{~mL}$ of malt extract broth (MEB) medium. Static cultivation was carried out for 4 weeks at temperature of $27-29^{\circ} \mathrm{C}$.

\subsection{Fungi Extraction}

Fungi extraction was conducted according to Nursid, Pratitis, and Chasanah (2010). Mycelium and broth were extracted separately. Broth was extracted using ethyl acetate and the mycelium was extracted by maceration using a mixture of methanol: dichloromethane $(v / v=1: 1)$. Each extraction solvent was then concentrated by vacuum evaporator. The remaining solvent contained in the extract was then dried by vacuum concentrator.

\subsection{Antioxidant Assay}

The antioxidant assay was conducted according to Batubara, Mitsunaga and Ohashi (2009). The dried extracts were dissolved in methanol then diluted to final concentrations of $100,200,400,800$, and 1600 $\mu \mathrm{g} / \mathrm{ml}$ as sample solutions. A total of $100 \mu \mathrm{L}$ of sample solution and $100 \mu \mathrm{L}$ of $125 \mu \mathrm{M}$ DPPH solution were put into a 96-well plate. Samples were incubated at room temperature for 30 minutes. After that, the absorbance was measured at a wavelength of 517 $\mathrm{nm}$ using a microplate reader (Thermo Fisher Scientific). Ascorbic acid was used as positive control. Antioxidant activity was calculated by the following equation:

$$
\text { Inhibition }(\%)=\left[\left(A_{\text {blank }}-A_{\text {sample }}\right) /\left(A_{\text {blank }}\right)\right] \times 100 \%
$$

$I_{50}$ value was determined from the correlation of each concentration with the percentage of DPPH inhibition.

\subsection{Tyrosinase Inhibition Assay}

Tyrosinase Inhibition Assay was conducted according to Batubara and Adfa (2013). The sample was dissolved with DMSO as a stock solution. Range of concentrations were prepared $(31.25 ; 62.5 ; 125$; 250 ; and $500 \mu \mathrm{g} / \mathrm{ml}$ ) by dissolving concentrated extract using phosphate buffer ( $\mathrm{pH}$ 6.5). A total of $70 \mu \mathrm{L}$ of extract solution was put into a 96-well plate, then 30 $\mu \mathrm{L}$ tyrosinase enzyme (Sigma, 333 units of $\mathrm{mL}^{-1}$ in phosphate buffer solution) was added, and the mixture was incubated for 5 minutes. Then, $110 \mu \mathrm{L}$ of substrate (L-tyrosine $2 \mathrm{mM}$ ) was added then incubated at $37^{\circ} \mathrm{C}$ for 30 minutes. The absorbance was measured at a wavelength of $492 \mathrm{~nm}$ using microplate reader (Thermo Fisher Scientific). Kojic acid was used as a positive 
control. The inhibition activity was calculated by the following equation:

Inhibition $(\%)=\left[\left(A_{\text {Negative control }}-A_{\text {sampel }}\right) / A_{\text {Negative control }}\right] \times 100 \%$

$I_{50}$ values was determined from the correlation of each concentration with the percentage of tyrosinase inhibition.

\subsection{Antiglycation Assay}

Antiglycation activity assay was conducted according to Faturrahman (2016). The extract was dissolved in distilled water and prepared in a range of concentrations. Aminoguanidine was used as a positive control in a range of concentrations. The test solution was prepared, consisting of solution A containing $200 \mu \mathrm{L}$ phosphate buffer $200 \mathrm{mM}$ (pH 7.4), $80 \mu \mathrm{L}$ bovine serum albumin (BSA) $20 \mathrm{mg} / \mathrm{mL}, 40 \mu \mathrm{L}$ glucose $235 \mathrm{mM}$, and $40 \mu \mathrm{L}$ fructose $235 \mathrm{mM}$; solution B containing $200 \mu \mathrm{L}$ phosphate buffer $200 \mathrm{mM}(\mathrm{pH}$ 7.4), $80 \mu \mathrm{L}$ BSA $20 \mathrm{mg} / \mathrm{mL}$; solution C containing 200 $\mu \mathrm{L}$ phosphate buffer $200 \mathrm{mM}$ (pH 7.4), $80 \mu \mathrm{L}$ BSA 20 $\mathrm{mg} / \mathrm{mL}, 40 \mu \mathrm{L}$ glucose $235 \mathrm{mM}, 40 \mu \mathrm{L}$ fructose 235 $\mathrm{mM}$, and $80 \mu \mathrm{L}$ extract/aminoguanidine, and solution D containing $200 \mu \mathrm{L}$ phosphate buffer $200 \mathrm{mM}(\mathrm{pH}$ 7.4), $80 \mu \mathrm{L}$ BSA $20 \mathrm{mg} / \mathrm{mL}$, and $80 \mu \mathrm{L}$ extract/ aminoguanidine. All test solutions were incubated at $60{ }^{\circ} \mathrm{C}$ for 40 hours. Each solution was pipetted as much as $100 \mu \mathrm{L}$ into a 96-well plate. The relative amount of BSA emitted was measured using a fluorometer at an excitation wavelength of $370 \mathrm{~nm}$ and an emission of $440 \mathrm{~nm}$. Antiglycation activity is determined by the following formula:

$$
\text { Inhibition }(\%)=[1-(C-D) /(A-B)] \times 100 \%
$$

Note:

A: Fluorescence intensity of solution A (glycation control)

B: Fluorescence intensity of solution $B$ (correction of glycation control)

C: Fluorescence intensity of solution C (sample)

D: Fluorescence intensity of solution D (correction of sample)

$\mathrm{IC}_{50}$ value was determined from the correlation of each concentration with the percentage of protein glycation inhibition.

\section{Result and Discussion}

\subsection{Fungi Cultivation}

The fungi isolates used in this study were 28 isolates in total. All of them were culture collections of RCMFPPB. The isolates were isolated from the surface of marine invertebrates (such as sponges, soft corals, and ascidians) that were taken from Kepulauan Seribu Marine National Park, DKI Jakarta. The isolates were preserved at $-73^{\circ} \mathrm{C}$ in MEA medium containing $10 \%$ glycerol. Before the fungi was cultivated in MEB liquid medium, it was refreshed in MEA solid medium. Refreshment was aimed to get young spores so that they can produce better products (Wuryanti, 2008). It was also aimed to find out the cultivated fungi was a monoculture without other microbial contaminants. MEA medium is commonly used for endophytic fungus isolation and culture because the medium contains nutrients needed for fungi growth. MEA medium contains malt extract, yeast extract, and peptone dissolved in seawater. Malt extract acts as an energy source for fungi. Yeast extract is rich in B vitamins, carbohydrates, and nitrogen so that it can enrich nutrients in the medium. Pepton contains free amino acids, peptides, and proteases which are the main sources of nitrogen. Fungi was refreshed for $4-5$ days at room temperature and static conditions. On the fourth day, the mycelium had grown. Each isolate had a different mycelium color and shape.

\subsection{Antioxidant Activity}

Screening of antioxidant activity of fungi extract carried out at doses of $1,000 \mu \mathrm{g} / \mathrm{mL}$ are showed in varied results (Table 1). ANOVA test results showed that different fungi strains affected DPPH free radical scavenging activity $(p<0.05)$. There were five broth extracts which had a scavenging capacity of free radicals above $50 \%$ namely MFP 144 , MFP 152 , MFP 218, MFP 280, and MFP 282. In the mycelium extract, there were also 5 extracts that had a scavenging capacity of free radicals above $50 \%$ namely MFP 152, MFP 270, MFP 272, and MFP 280. Based on the results of the initial screening, further test of 5 extracts of broth and mycelium was carried out using series of concentration to obtain $\mathrm{IC}_{50}$ values. The $\mathrm{IC}_{50}$ values obtained were very diverse, but in general the $I_{50}$ value of each extract was above $100 \mu \mathrm{g} / \mathrm{mL}$ (Table 2). Molyneux (2004) classified antioxidant activity based on $\mathrm{IC}_{50}$ values, e.g. very strong $(<50 \mu \mathrm{g} / \mathrm{mL})$, strong $(50-100 \mu \mathrm{g} / \mathrm{mL})$, weak $(150-200 \mu \mathrm{g} / \mathrm{mL})$, and very weak ( $>200 \mu \mathrm{g} / \mathrm{mL}$ ). Based on this, the extract of broth and mycelium are classified as very weak.

Antioxidants are electron donor compounds or reducing agents. Antioxidants can inhibit oxidation reactions by capturing free radicals and highly reactive molecules. Reactive oxygen species (ROS) are an oxidant produced in the body that can trigger oxidative stress and cause tissue dysfunction and degenerative diseases (Ali et al., 2008). Antioxidant activity test was carried out by DPPH method based on the ability 
Table 1. Antioxidant activity of broth and mycelium extract by using DPPH assay at dose 1,000 $\mu \mathrm{g} / \mathrm{ml}$

\begin{tabular}{|c|c|c|c|}
\hline \multirow{2}{*}{ No } & \multirow{2}{*}{ Fungi Isolates } & \multicolumn{2}{|c|}{ Free Radical Scavenging (\%) } \\
\hline & & Broth Extract & Mycelium Extract \\
\hline 1 & MFP 142 & $41.64 \pm 4.25^{\mathrm{fg}}$ & $21.41 \pm 4.25^{d}$ \\
\hline 2 & MFP 144 & $54.91 \pm 2.81^{\mathrm{ij}}$ & $27.78 \pm 2.81^{\mathrm{e}}$ \\
\hline 3 & MFP 148 & $48.09 \pm 5.72^{h}$ & $12.02 \pm 5.72^{b c}$ \\
\hline 4 & MFP 149 & $13.63 \pm 0.63^{b}$ & $17.28 \pm 0.63^{c d}$ \\
\hline 5 & MFP 152 & $71.07 \pm 0.21^{1}$ & $67.82 \pm 0.21^{\mathrm{m}}$ \\
\hline 6 & MFP 158 & $41.22 \pm 1.77^{\mathrm{fg}}$ & $16.91 \pm 1.77^{\mathrm{cd}}$ \\
\hline 7 & MFP 171 & $45.39 \pm 0.43^{g h}$ & $16.98 \pm 0.43^{\mathrm{cd}}$ \\
\hline 8 & MFP 172 & $47.81 \pm 1.35^{\mathrm{h}}$ & $5.84 \pm 1.35^{\mathrm{a}}$ \\
\hline 9 & MFP 175 & $30.44 \pm 0.43 d^{e}$ & $16.38 \pm 0.43^{\mathrm{cd}}$ \\
\hline 10 & MFP 217 & $16.91 \pm 1.30^{b}$ & $9.16 \pm 1.30 \mathrm{ab}$ \\
\hline 11 & MFP 218 & $61.75 \pm 6.95^{\mathrm{k}}$ & $5.66 \pm 6.95 a$ \\
\hline 12 & MFP 221 & $24.76 \pm 2.13^{\mathrm{cd}}$ & $19.64 \pm 2.13^{d}$ \\
\hline 13 & MFP 222 & $31.49 \pm 3.19^{e}$ & $26.65 \pm 3.19^{\mathrm{e}}$ \\
\hline 14 & MFP 224 & $12.14 \pm 1.37^{b}$ & $29.01 \pm 1.37^{\text {ef }}$ \\
\hline 15 & MFP 225 & $41.11 \pm 1.67^{\mathrm{gg}}$ & $42.55 \pm 0.77^{g i}$ \\
\hline 16 & MFP 270 & $37.21 \pm 0.77^{f}$ & $56.82 \pm 1.57^{\mathrm{kl}}$ \\
\hline 17 & MFP 271 & $6.69 \pm 1.57^{\mathrm{a}}$ & $55.35 \pm 0.87^{\mathrm{kl}}$ \\
\hline 18 & MFP 272 & $46.38 \pm 0.87^{g h}$ & $60.21 \pm 0.87^{1}$ \\
\hline 19 & MFP 274 & $25.58 \pm 5.52^{\mathrm{cd}}$ & $41.06 \pm 5.52^{g h}$ \\
\hline 20 & MFP 276 & $23.68 \pm 2.36^{c}$ & $40.04 \pm 2.36^{g h}$ \\
\hline 21 & MFP 277 & $38.78 \pm 2.18^{f}$ & $41.37 \pm 2.18^{g h}$ \\
\hline 22 & MFP 278 & $49.38 \pm 0.63^{\mathrm{hi}}$ & $44.82 \pm 0.63^{\mathrm{hi}}$ \\
\hline 23 & MFP 279 & $26.34 \pm 1.20^{\text {cde }}$ & $38.95 \pm 1.20^{\mathrm{g}}$ \\
\hline 24 & MFP 280 & $58.20 \pm 1.40^{\mathrm{jk}}$ & $52.00 \pm 1.40^{\mathrm{jk}}$ \\
\hline 25 & MFP 281 & $27.17 \pm 0.62^{\mathrm{cde}}$ & $47.42 \pm 0.62^{\mathrm{ij}}$ \\
\hline 26 & MFP 282 & $54.35 \pm 3.48^{\mathrm{ij}}$ & $38.70 \pm 3.48^{f}$ \\
\hline 27 & MFP 283 & $48.23 \pm 0.38^{h}$ & $19.07 \pm 0.38^{d}$ \\
\hline 28 & MFP 284 & $25.10 \pm 1.52^{\mathrm{cd}}$ & $20.08 \pm 1.52^{d}$ \\
\hline
\end{tabular}

Note: different letters (a-m) showed significant differences $(\alpha=0.05)$

of an antioxidant to donate protons to radical DPPH (Jafari et al., 2016). This method is often used to test antioxidant activity because of several advantages, namely direct inhibition measurement, simple, and fast (Kaewnarin, Niamsup, Shank \& Rakariyatham, 2014).

The antioxidant activity of fungi in this research was classified as very weak. This was probably due to the tested extract was crude extract and also contained a lot of salt from the medium. In this study, the media used contained sea water with salinity of $30 \%$. Even though, some reports explained that marine fungi have strong antioxidant compounds. $\mathrm{Li}$ et al. (2014) reported that Aspergillus wentii EN-48 fungi produced metabolites of anthraquinone compounds which had DPPH free radical scavenging activity with $\mathrm{IC}_{50}$ values ranging from 5.2 to $99.4 \mu \mathrm{g} /$ $\mathrm{mL}$. Aspergillus terreus LS01 produced active terreic 
Table 2. DPPH assay $I C_{50}$ value of selected marine fungi

\begin{tabular}{|c|c|c|}
\hline No & Fungi Isolates & $\mathrm{IC}_{50}(\mu \mathrm{g} / \mathrm{mL})$ \\
\hline \multicolumn{3}{|c|}{ Broth Extract } \\
\hline 1 & MFP 144 & $963.51 \pm 299.72^{c d}$ \\
\hline 2 & MFP 152 & $1,502.01 \pm 429.65^{\mathrm{e}}$ \\
\hline 3 & MFP 218 & $1,256.77 \pm 283.13^{\mathrm{de}}$ \\
\hline 4 & MFP 280 & $591.67 \pm 18.20^{\mathrm{bc}}$ \\
\hline 5 & MFP 282 & $916.66 \pm 52.98^{\mathrm{cd}}$ \\
\hline \multicolumn{3}{|c|}{ Mycelium Extract } \\
\hline 6 & MFP 152 & $1,130.24 \pm 668.93^{\mathrm{de}}$ \\
\hline 7 & MFP270 & $289.20 \pm 136.07^{\mathrm{ab}}$ \\
\hline 8 & MFP271 & $287.25 \pm 49.76^{\mathrm{ab}}$ \\
\hline 9 & MFP272 & $787.07 \pm 55.52^{\mathrm{ab}}$ \\
\hline 10 & MFP280 & $526.88 \pm 16.17^{\text {be }}$ \\
\hline 11 & Ascorbic Acid & $6.55 \pm 0.77^{\mathrm{a}}$ \\
\hline
\end{tabular}

acid and terremutin metabolites which can reduce $\mathrm{DPPH}$ free radicals with $\mathrm{IC}_{50}$ values of $0.115 \pm 4.02$ and $0.114 \pm 2.19 \mathrm{mM}$, respectively (Dewi et al., 2012).

\subsection{Tyrosinase Inhibitor}

The screening of tyrosinase inhibitor activity results at a dose of $1,000 \mu \mathrm{g} / \mathrm{mL}$ from the medium extract showed that extract of MFP 152 strain had the most powerful activity, which was $42.74 \%$. Compared to broth extracts, mycelium extract showed stronger activity. The high activity in the mycelium extract was shown by extracts of MFP 272, MFP 276, and MFP 277 with inhibition values of $58.80 \%, 62.15 \%$, and $45.01 \%$, respectively (Table 3 ).

The broth and mycelium extract were further tested to obtain $\mathrm{IC}_{50}$ value using kojic acid as a positive control. The test results showed that MFP 272 has the smallest $I C_{50}$ value of $742.31 \mu \mathrm{g} / \mathrm{mL}$. Kojic acid as a positive control has an $\mathrm{IC}_{50}$ value of $119.40 \mu \mathrm{g} / \mathrm{mL}$ (Table 4).

ANOVA test showed that different fungus strain affected tyrosinase inhibition $(p<0.05)$. The $I_{50}$ calculation from the four extracts showed that the MFP 277 mycelium extract had the best activity but not significantly different from the MFP 272, MFP 276, and MFP 277 mycelium extract. Compared to kojic acid which has $I_{50}$ value of $119.40 \mu \mathrm{g} / \mathrm{mL}$, the activity of MFP fungi 272, MFP 276, and MFP 277 was still considered as weak. For the same reason, the weak activity of tyrosinase inhibitor was probably due to the extract used in the form of crude which still contains a large amount of salt from the media

Tyrosinase is a copper-containing enzyme or metaloenzyme which is widely distributed in nature, including bacteria, fungi, plants, and animals. In mammals, tyrosinase plays a role in pigmentation of the skin, eyes, and hair (Chang, 2012). Tyrosinase is involved in the pigmentation process, by changing the L-tyrosine substrate into L-DOPA and converting the L-DOPA substrate into dopaquinone (Tang, Zhang, Zhao, \& Chen, 2015). High reactivity of DOPA or dopaquinone causes spontaneous polymerization reactions to form melanin (brown pigment). The mechanism of melanin formation is the enzyme tyrosinase catalyzes tyrosine into 3,4dihydroxyphenylalanine (DOPA), then DOPA is oxidized to dopaquinone and then occurs reactions that produce eumelanin or feomelanin pigments (Likhitwitayawuid, 2008).

Marine-derived fungi containing tyrosinase inhibiting compounds for example from Pestalotiopsis sp. strain Z233 have been isolated from the brown algae Sargassum horneri. Sesqueterpene group compounds of $1 \beta, 5 \alpha, 6 \alpha, 14$-tetraacetoxy- $9 \alpha$ benzoyloxy- $7 \beta \mathrm{H}$-eudesman-2 $\beta, 11$-diol and $4 \alpha, 5 \alpha$ diacetoxy- $9 \alpha$-benzoyloxy- $7 \beta \mathrm{H}$-eudesman- $1 \beta$, $2 \beta, 11,14$-tetraol showed tyrosinase inhibitory activities with $\mathrm{IC}_{50}$ value of $14.8 \mu \mathrm{M}$ and $22.3 \mu \mathrm{M}$, respectively (Wu et al., 2013). Meanwhile El-Hady et al. (2014) 
Table 3. Tyrosinase inhibitor activity of broth and mycelium extract

\begin{tabular}{|c|c|c|c|}
\hline \multirow{2}{*}{ No } & \multirow{2}{*}{ Fungi Isolates } & \multicolumn{2}{|c|}{ Inhibition of Tyrosinase (\%) } \\
\hline & & Broth Extracts & Mycelium Extracts \\
\hline 1 & MFP 142 & $27.47 \pm 4.25^{\text {def ghij }}$ & $19.08 \pm 4.69^{\text {cdef }}$ \\
\hline 2 & MFP 144 & $22.04 \pm 0.09^{\mathrm{abcde}}$ & $19.95 \pm 3.31^{\text {cdef }}$ \\
\hline 3 & MFP 148 & $25.60 \pm 1.66^{\text {bcdefgh }}$ & $37.23 \pm 5.7^{\text {ghij }}$ \\
\hline 4 & MFP 149 & $20.15 \pm 6.21^{\mathrm{abcd}}$ & $32.19 \pm 4.54^{g h}$ \\
\hline 5 & MFP 152 & $42.74 \pm 1.73^{m}$ & $29.21 \pm 6.96^{f g}$ \\
\hline 6 & MFP 158 & $22.53 \pm 3.02^{\text {abcdef g }}$ & $16.53 \pm 8.36^{\text {bcde }}$ \\
\hline 7 & MFP 171 & $29.55 \pm 6.57^{\text {ef ghijk }}$ & $2.47 \pm 9.29^{a}$ \\
\hline 8 & MFP 172 & $34.07 \pm 3.46^{\mathrm{ijkl}}$ & $14.84 \pm 6.32^{\mathrm{bcd}}$ \\
\hline 9 & MFP 175 & $31.09 \pm 5.46^{g \mathrm{hijkl}}$ & $11.78 \pm 4.10^{\text {cdef }}$ \\
\hline 10 & MFP 217 & $23.40 \pm 2.98^{\text {abcdef } g}$ & $32.67 \pm 4.81^{\text {efg }}$ \\
\hline 11 & MFP 218 & $21.53 \pm 6.11^{\mathrm{abcd}}$ & $25.44 \pm 3.50^{\text {bcde }}$ \\
\hline 12 & MFP 221 & $17.30 \pm 0.39^{a}$ & $25.44 \pm 3.50^{\operatorname{defg}}$ \\
\hline 13 & MFP 222 & $18.15 \pm 0.75^{\mathrm{ab}}$ & $20.93 \pm 4.07^{\text {cdef }}$ \\
\hline 14 & MFP 224 & $19.29 \pm 2.22^{\mathrm{abc}}$ & $18.30 \pm 3.91^{\text {bcdef }}$ \\
\hline 15 & MFP 225 & $37.73 \pm 4.66^{\mathrm{lm}}$ & $2.30 \pm 0.20^{\mathrm{a}}$ \\
\hline 16 & MFP 270 & $37.12 \pm 2.94^{\mathrm{km}}$ & $8.42 \pm 1.02^{\mathrm{abc}}$ \\
\hline 17 & MFP 271 & $31.08 \pm 1.41^{g h i j k l}$ & $6.62 \pm 6.28^{\mathrm{ab}}$ \\
\hline 18 & MFP 272 & $30.09 \pm 1.51^{\mathrm{fghijkl}}$ & $58.80 \pm 7.2^{4 k}$ \\
\hline 19 & MFP 274 & $36.02 \pm 1.05^{\mathrm{klm}}$ & $43.98 \pm 6.04^{j}$ \\
\hline 20 & MFP 276 & $36.10 \pm 8.28^{\mathrm{klm}}$ & $62.15 \pm 1.62^{k}$ \\
\hline 21 & MFP 277 & $31.48 \pm 0.84^{\mathrm{hijkl}}$ & $45.01 \pm 4.08^{\mathrm{ij}}$ \\
\hline 22 & MFP 278 & $19.75 \pm 1.07^{\mathrm{abcd}}$ & $18.77 \pm 8.34^{\text {bcde }}$ \\
\hline 23 & MFP 279 & $30.61 \pm 7.84^{g \mathrm{hijkl}}$ & $18.85 \pm 5.17^{\text {cdef }}$ \\
\hline 24 & MFP 280 & $24.64 \pm 0.78^{\text {cdef ghi }}$ & $33.98 \pm 5.47^{g h i}$ \\
\hline 25 & MFP 281 & $24.64 \pm 0.78^{\text {abcdef gh }}$ & $1.64 \pm 3.96^{\mathrm{a}}$ \\
\hline 26 & MFP 282 & $35.60 \pm 5.28^{\mathrm{jkl}}$ & $18.65 \pm 5.16^{\text {cdef }}$ \\
\hline 27 & MFP 283 & $30.25 \pm 4.96^{g \mathrm{hijkl}}$ & $38.93 \pm 9.10^{\mathrm{hij}}$ \\
\hline 28 & MFP 284 & $20.79 \pm 6.79^{\mathrm{abcdef}}$ & $16.57 \pm 7.82^{\mathrm{bcde}}$ \\
\hline
\end{tabular}

Table 4. Tyrosinase inhibitor assay $\mathrm{IC}_{50}$ value of selected marine fungi

\begin{tabular}{|c|c|c|}
\hline No & Fungi Isolates & $\mathrm{IC}_{50}(\mu \mathrm{g} / \mathrm{mL})$ \\
\hline \multicolumn{3}{|c|}{ Broth Extract } \\
\hline 1 & MFP 152 & $1,0921.28 \pm 23.15^{c}$ \\
\hline \multicolumn{3}{|c|}{ Mycelium Extract } \\
\hline 2 & MFP 272 & $742.31 \pm 146.02^{b}$ \\
\hline 3 & MFP 276 & $769.02 \pm 16.31^{\mathrm{b}}$ \\
\hline 4 & MFP 277 & $586.42 \pm 74.44^{b}$ \\
\hline 5 & Kojic acid & $119.40 \pm 11.80^{\mathrm{a}}$ \\
\hline
\end{tabular}

Note: different letters (a-c) showed significant differences ( $\alpha=0.05)$ 
Table 5. Antiglycation activity of broth and mycelium extract

\begin{tabular}{|c|c|c|c|}
\hline \multirow{2}{*}{ No } & \multirow{2}{*}{ Fungi Isolates } & \multicolumn{2}{|c|}{ AGEs Inhibition (\%) } \\
\hline & & Broth Extract & Mycelium Extract \\
\hline 1 & MFP 142 & $47.02 \pm 3.41^{1 \mathrm{mn}}$ & $-23.21 \pm 0.00^{\operatorname{def} g}$ \\
\hline 2 & MFP 144 & $-48.52 \pm 8.10^{a}$ & $-15.17 \pm 0.00^{\mathrm{hij}}$ \\
\hline 3 & MFP 148 & $69.78 \pm 0.01^{q}$ & $17.59 \pm 7.86^{1}$ \\
\hline 4 & MFP 149 & $-1.82 \pm 0.01^{b c}$ & $-27.18 \pm 0.00^{\text {cde }}$ \\
\hline 5 & MFP 152 & $0.52 \pm 0.87^{\mathrm{bc}}$ & $-24.79 \pm 0.00^{\text {cdef }}$ \\
\hline 6 & MFP 158 & $36.03 \pm 0.01^{\text {ghij }}$ & $-23.48 \pm 0.41^{\operatorname{defg}}$ \\
\hline 7 & MFP 171 & $23.93 \pm 0.01^{\mathrm{ef}}$ & $-16.03 \pm 3.21^{\text {ghij }}$ \\
\hline 8 & MFP 172 & $55.81 \pm 8.95^{\text {no }}$ & $-19.71 \pm 0.59^{\text {ef ghi }}$ \\
\hline 9 & MFP 175 & $33.48 \pm 5.37^{f g h i}$ & $-26.72 \pm 0.12^{\text {cde }}$ \\
\hline 10 & MFP 217 & $10.54 \pm 6.02^{d}$ & $1.14 \pm 4.22^{k}$ \\
\hline 11 & MFP 218 & $3.75 \pm 2.25^{\mathrm{cd}}$ & $7.90 \pm 0.01^{\mathrm{k}}$ \\
\hline 12 & MFP 221 & $56.46 \pm 0.01^{\text {nop }}$ & $-21.24 \pm 0.00^{\text {efgh }}$ \\
\hline 13 & MFP 222 & $46.67 \pm 0.01^{\mathrm{kln}}$ & $-21.69 \pm 0.00^{\text {defgh }}$ \\
\hline 14 & MFP 224 & $65.75 \pm 1.27^{\mathrm{pq}}$ & $-19.03 \pm 0.00^{f g h i}$ \\
\hline 15 & MFP 225 & $37.15 \pm 1.06^{\mathrm{hijk}}$ & $-15.96 \pm 0.00^{g h i j}$ \\
\hline 16 & MFP 270 & $-8.53 \pm 3.51^{b}$ & $21.25 \pm 1.04$ \\
\hline 17 & MFP 271 & $52.18 \pm 0.01^{\mathrm{mno}}$ & $-8.79 \pm 0.00^{\mathrm{j}}$ \\
\hline 18 & MFP 272 & $32.05 \pm 8.91^{\mathrm{fghi}}$ & $-10.88 \pm 0.00^{j}$ \\
\hline 19 & MFP 274 & $59.60 \pm 1.01^{\mathrm{op}}$ & $-34.55 \pm 0.00^{\mathrm{ab}}$ \\
\hline 20 & MFP 276 & $28.72 \pm 0.00^{\mathrm{efgh}}$ & $-31.50 \pm 0.00^{\mathrm{bc}}$ \\
\hline 21 & MFP 277 & $26.7 \pm 7.80^{\text {efg }}$ & $-13.28 \pm 0.00^{\mathrm{ij}}$ \\
\hline 22 & MFP 278 & $48.02 \pm 0.66^{\operatorname{lmn}}$ & $-9.07 \pm 0.00^{\mathrm{j}}$ \\
\hline 23 & MFP 279 & $33.46 \pm 7.27^{f g h i}$ & $-39.44 \pm 0.00^{\mathrm{a}}$ \\
\hline 24 & MFP 280 & $40.19 \pm 0.06^{\mathrm{ijkl}}$ & $-28.93 \pm 0.00^{b c d}$ \\
\hline 25 & MFP 281 & $24.63 \pm 12.25^{\mathrm{ef}}$ & $-26.31 \pm 0.00^{\text {cdef }}$ \\
\hline 26 & MFP 282 & $56.44 \pm 7.16^{\text {nop }}$ & $-38.93 \pm 0.00^{a}$ \\
\hline 27 & MFP 283 & $19.80 \pm 10.43^{\mathrm{e}}$ & $-21.74 \pm 0.00^{\text {def } g h}$ \\
\hline 28 & MFP 284 & $45.48 \pm 8.26^{\mathrm{jklm}}$ & $6.25 \pm 2.10^{k}$ \\
\hline
\end{tabular}

Note: different letters $(a-c)$ showed significant differences $(\alpha=0.05)$

reported that marine fungi Aspergillus sydowiistrain W4-2 isolated from sponge Amphimedon viridis had moderate activity against tyrosinase.

\subsection{Antiglycation}

The results of the antiglycation activity screening of the extract at a concentration of $1,000 \mu \mathrm{g} / \mathrm{mL}$ generally showed that the medium extract had a better activity than the mycelium extract (Table 5).

ANOVA test results showed that different fungi strain affects the inhibition percentage of AGEs ( $p$ $<0.05)$. There were 7 extracts which had activity above
$50 \%$, namely, MFP 148, MFP 172, MFP 221, MFP 224, MFP 271, MFP 274, and MFP 282. Broth extracts from MFP 274 and MFP 224 had the best antiglycation activity with the $\mathrm{IC}_{50}$ values of $298.57 \mu \mathrm{g} /$ $\mathrm{mL}$ and $328.80 \mu \mathrm{g} / \mathrm{mL}$, respectively (Table 6). Statistically, the activity of AGEs inhibition of MFP 274 extract was not significantly different from MFP 224 , but the $I C_{50}$ values of both extracts were significantly different from $\mathrm{IC}_{50}$ of aminoguanidine which was $73.25 \mu \mathrm{g} / \mathrm{mL}$ so that the extract of MFP 274 and MFP 224 medium was still not effective enough to inhibit the formation of AGEs compared to aminoguanidine. 
Table 6. IC ${ }_{50}$ value of AGEs inhibition of selected marine fungi

\begin{tabular}{ccc}
\hline No & Fungi Isolates & IC $_{50}(\boldsymbol{\mu g} / \mathbf{m L})$ \\
\hline 1 & MFP 148 & $901.90 \pm 178.23^{\mathrm{C}}$ \\
2 & MFP 172 & $947.84 \pm 129.74^{\mathrm{C}}$ \\
3 & MFP 221 & $970.63 \pm 150.90^{\mathrm{c}}$ \\
4 & MFP 224 & $328.80 \pm 64.65^{\mathrm{b}}$ \\
5 & MFP 271 & $978.80 \pm 25.08^{\mathrm{c}}$ \\
6 & MFP 274 & $298.57 \pm 73.87^{\mathrm{b}}$ \\
7 & MFP 282 & $946.87 \pm 85.19^{\mathrm{c}}$ \\
Note: different letters (a-c) showed significant differences $(\alpha=0.05)$
\end{tabular}

AGEs are a group of compounds that is used as an indicator for protein modification by reducing sugars produced in the Maillard reaction. The Maillard reaction begins with the formation of Schiff bases between aldehyde groups of reducing sugars with amino acids from proteins or nucleic acids. Rearrangement reactions in the Schiff base produce a more stable, toxic, and able to react with amino acids amadori products (Al-Farabi, 2013). Accumulation of AGEs in dermal tissue will increase the stress of glycation on the skin. AGEs will interact with collagen in the epidermal layer of the skin which accelerates skin aging. AGEs can also produce reactive free radicals that will accelerate protein glycation reactions (Ndlovu et al., 2013).

Protein glycation occurs when the reaction between albumin and reducing sugars produces glycated proteins. Albumin used in the assay comes from the mammalian blood component, i.e. BSA. BSA has the highest glycation sensitivity to AGEs with the highest relative fluorescense (RF) values compared to other amine sources. Glucose, fructose, and ribose can be used as compounds that initiate glycation. Glucose is chosen to reduce sugar in the in vitro protein glycation model, because its concentration is proportional to the level of sugar in human blood. In addition, fructose which has a higher reactivity than glucose can be chosen to increase the effectiveness of the formed AGEs (Hori et al., 2012).

The glycated protein changes the structure and molecular weight that contains highly reactive free radicals. These free radicals then form intra- and intermolecular cross-linkages involved in body biochemical abnormalities associated with aging and diabetes. Compounds that also act as free radical trappers can be more effective in inhibiting the formation of AGEs. Antioxidants can inhibit monosaccharide autoxidation, prevent oxidation of amadori products, and reduce the reactivity of Maillard reactions intermediate dicarbonyl compounds (Vauzour, Mateos, Corona, Concha \& Spencer, 2010). Aminoguanidine which is a synthetic drug is often used as an inhibitor of the formation of AGEs because it is able to trap carbonyl intermediates in the Maillard reaction. However, long-term use of aminoguanidine has the potential to cause toxic effects in the body (Shen, Su \& Sheng, 2017). In this test, protein glycation inhibition was determined based on fluorescence intensity on the test solution consisting of glycation control, positive control, and the extract. The smaller the fluorescence intensity produced by a test solution, indicating that fewer AGEs are formed and the greater the inhibitory power. Incubation of the solution is carried out at a temperature of $60{ }^{\circ} \mathrm{C}$ for 40 hours because the temperature and time are the general condition of the protein glycation reaction. Measurement of AGEs can be done using a flourometry method. Flourimeter (fluorescence spectrometry) is a device used to measure a compound through the intensity and distribution of emissions emitted (Lakowicz, 2006).

Overall, based on the screening results conducted in this study, fungal strain with the best antioxidant activity was MFP 271 (mycelium extract), the best tyrosinase inhibitor was shown by MFP 277 (mycelium extract) and the best antiglycation was shown by 274 MFP (mycelium extract) (Figure 1). The MFP 271 and MFP 274 were isolated from an ascidan surface while the MFP 277 was isolated from the soft coral surface. Both hosts were obtained from the waters around the Pulau Panggang, Kepulauan Seribu, Indonesia.

Preliminary observations result showed that the morphology of the fungi was characterised as Aspergillus. This is parallel with Bugni and Ireland (2004) statement that the most active compounds isolated from marine fungi come from the Aspergillus and Penicillium groups. Aspergillus and Penicillium are known to have cosmopolitan properties and can be found in various places. In addition, the two fungi 

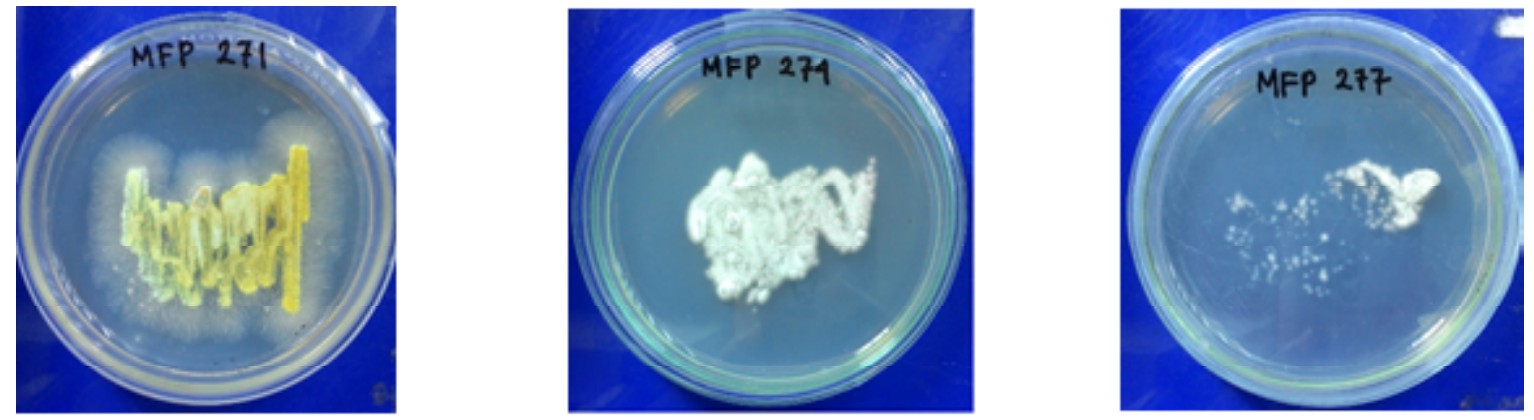

Figure 1. Fungi colonies of MFP271, MFP 274, and MFP 277 in MEA medium.

have a strong tolerance range in the high-salt environment. In this study, MFP 271 colonies were yellow while MFP 274 and MFP 277 colonies were white. To determine these fungus, it will need further research both microscopically and molecularly. In addition, fermentation is needed on a larger scale to obtain more extracts so that it is sufficient to isolate and identify the active compounds contained in the fungi.

Research on bioprospecting of marine fungi from Kepulauan Seribu Marine National Park was conducted by Fajarningsih, Pratitis, Wikanta and Chasanah (2012). Cytotoxicity screening was carried out to 46 marine fungi extracts againts HeLa and HepG2 cells. The screening showed that several marine fungi had promising cytotoxicity. Nursid, Chasanah, Murwantoko and Wahyuono (2011) tested cytotoxicity of marine fungi from several Indonesian waters (Manado waters, Kepulauan Seribu Marine National Park, and Wakatobi Marine National Park). One of the "hit" from the study was the MFW39 strain which had an inhibition of $35.5 \%$ to T47D cells. After being recultivated on $1 \mathrm{~L}$ scale, cytotoxicity of mycelium extract increased with $\mathrm{IC}_{50}$ of $21.9 \mu \mathrm{g} / \mathrm{ml}$. The research on bioprospecting of tyrosinase inhibitor and antiglycation from marine fungi collected from Kepulauan Seribu Marine National Park is still very limited. In this research, although the antioxidant, tyrosinase inhibitor and antiglycation activities of MFP 271, MFP 277 and MFP 274 were weak compared to the positive controls, the results of this study showed the potential of marine fungi from Kepulauan Seribu Marine National Park as a source of biomedical as well as cosmetic compounds. Therefore, the results of this research were also useful as information on marine fungi bioprospecting particularly as antioxidant, tyrosinase inhibitor, and antiglycation.

\section{Conclusion}

Broth and mycelium extracts have different activities on antioxidant, tyrosinase inhibitor, and antiglycation. Extract with the best antioxidant activity was MFP 271 mycelium extract $\left(\mathrm{IC}_{50} 287.256 \mu \mathrm{g} /\right.$ $\mathrm{mL}$ ). The extract which had the potential as a tyrosinase inhibitor was the MFP 277 mycelium extract $\left(\mathrm{IC}_{50} 586.42 \mu \mathrm{g} / \mathrm{mL}\right)$. The extract which had the potential was antiglycation was MFP 274 medium extract $\left(\mathrm{IC}_{50} 298.57 \mu \mathrm{g} / \mathrm{mL}\right)$. Compared to the control, bioactivity of the crude extracts tested were considered weak.

\section{References}

Ali, S.S., Kasoju, N., Luthra, A., Singh, A., Sharanabasava, H., Sahu, A., \& Bora, U. (2008). Indian medicinal herbs as sources of antioxidants. Food Research International, 41: 1-15. doi:10.1016/j.foodres.2007. 10.001.

Al-Farabi, M.J. (2013). Antibodi terhadap advanced glycation end product, cara mutakhir mencegah diabetes melitus. Cermin Dunia Kedokteran, 40 (11): 807-814.

Batubara, I. \& Adfa, M. (2013). Potensi daun kayu bawang (Protium javanicum) sebagai penghambat kerja enzim tirosinase. Sains \& Matematika, 1 (2): 5256.

Batubara, I., Mitsunaga, T., \& Ohashi, H. (2009). Screening antiacne potency of Indonesian medical plants: antibacterial, lipase inhibition, and antioxidant activities. Journal of Wood Science, 55: 230-235. doi:10.1007/s10086-008-1021-1.

Bugni, T.S. \& Ireland, C.M. (2004). Marine-Derived Fungi: a Chemically and Biologically Diverse Group of Microorganisms. Natural Product Reports, 21: 143163. doi: 10.1039/b301926h.

Chang, T.M. (2012). Tyrosinase and tyrosinase inhibitors. Journal of Biocatalysis \& Biotransformation. 1 (2): 1 2. doi:10.4172/2324-9099.1000e106.

Dewi, R.T., Tachibana, S., Itoh, K., \& llyas, M. (2012). Isolation of Antioxidant Compounds from Aspergillus terreus LS01. Journal of Microbial \& Biochemical Technology (4):10-014. doi:10.4172/1948-5948. 1000065.

El-Hady, F.K.A., Aziz, M.S.A., Shaker, K.H., \& El-Shahid, Z.A. (2014). Tyrosinase, Acetylcholinesterase Inhibitory Potential, Antioxidant and Antimicrobial Activities of sponge derived fungi with correlation to their GC/MS Analysis. Int. J. Pharm. Sci. Rev. Res., 26(2): 338-345. 
Fajarningsih, N.D., Pratitis A., Wikanta, T. \& Chasanah. (2012). Bioprospeksi kapang yang berasosiasi dengan biota laut asal Kepulauan Seribu sebagai antitumor T47D dan HepG2. Jurnal Pasca Panen dan Bioteknologi Kelautan dan Perikanan, 7(1): 21-30.

Fathurrahman, N.A. (2016). Inhibisi ekstrak air lima tanaman obat terhadap glikasi protein secara in vitro dan potensinya sebagai antipenuaan. [Skripsi]. Bogor (ID): Institut Pertanian Bogor.

Hong, J.H, Jang, S., Heo, Y.M., Min, M., Lee, H., Lee, Y.M., Lee, H. \& Kim, J.J. (2015). Investigation of marinederived fungal diversity and their exploitable biological activities. Marine Drugs, 13: 4137-4155. doi:10.3390/ md13074137.

Hori, M., Yagi, M., Nomoto, K., Ichijo, R., Shimode, A., Kitano, T., \& Yonei, Y. (2012). Experimental models for advanced glycation end product formation using albumin, collagen, elastin, keratin and proteoglycan. Anti-Aging Medicine, 9 (5): 125-134.

Ichihashi, M., Yagi, M., Nomoto, K., \& Yonei, Y. (2011). Glycation stress and photo-aging in skin. Anti-Aging Medicine, 8 (3): 23-29.

Jafari, A.A., Miroliaei, M., Angelova, V.T., Emamzadeh, R., Djukic, M.M., Djuric, A. \& Saso L. (2016). Antioxidant activity and protective role on protein glycation of synthetic aminocoumarine. Electronic Journal of Biotechnology, 8 (4): 1-6.

Kaewnarin, K., Niamsup, H., Shank, L. \& Rakariyatham, N. (2014). Antioxidant and antiglycation activities of some edible and medicinal plants. Chiang Mai Journal of Science, 41(1): 105-116.

Kjer, J., Debbab, A., Aly, H., \& Proksch, P. (2010). Methods for isolation of marine-derived endophytic fungi and their bioactive secondary products. Nature Protocols, 5 (3): 479- 490. doi: 10.1038/nprot.2009.233

Kumala, S. \& Fitri, N.A. (2008). Penapisan kapang endofit kayu meranti merah (Shorea balangeran Korth.) sebagai penghasil enzim xilanase. Jurnal IImu Kefarmasian Indonesia, 6 (1): 1-6.

Lakowicz J.R. (2006). Principles of fluorescence spectroscopy: Washington (US): Springer Science.

Li, X., Li, X.M., Xu, G.M., Li, C.S., \& Wang, B.G. (2014). Antioxidant metabolites from marine alga-derived fungus Aspergillus wentii EN-48. Phytochemistry Letters, 7: 120-123. doi:10.1016/j.phytol.2013.11.008

Likhitwitayawuid, K. (2008). Stilbenes with tyrosinase inhibitory activity. Current Science, 94 (1): 44-52.

Molyneux, P. (2004). The use of the stable free radical diphenylpicrylhydrazil (DPPH) for estimating antioxidant activity. Songklanakarin Journal Science and Technology, 26(2): 211-219.

Ndlovu, G., Gerda, F., Malefa, T., Werner, C., \& Vanessa, S. (2013). In vitro determination of the anti-aging potential of four southern African medicinal plants. BMC Complementary and Alternative Medicine, 13 (304): 1-7. doi: 10.1186/1472-6882-13-304
Nursid, M., Pratitis, A., \& Chasanah, E. (2010). Kultivasi kapang MFW-01-08 yang diisolasi dari ascidia Aplidium longithorax dan uji aktivitas sitotoksiknya terhadap sel kanker payudara T47D. Jurnal Pasca Panen dan Bioteknologi Kelautan dan Perikanan, 5(2): 103-110.

Nursid, M., Chasanah, E., Murwantoko \& Wahyuono, S. (2011). Penapisan kapang laut penghasil senyawa sitotoksik dari beberapa perairan di Indonesia. Jurnal Pasca Panen dan Bioteknologi Kelautan dan Perikanan, 6(1): 45 - 54.

Posagi, J. \& Bara, R.A. (2014). Analisis aktivitas dari jamur endofit yang terdapat dalam tumbuhan bakau Avicennia marina di Tasik Ria Minahasa. Jurnal Pesisir dan Laut Tropis, 1 (1): 30-38.

Povichit, N., Phrutivorapongkul, A., Suttaji, M., Chaiyasut, C., \& Leelapornpisid, P. (2010). Antiglycation and antioxidant activities of oxyresveratol extracted from the heartwood of Artocarpus lakoocha Roxb. Maejo International Journal of Science and Technology, 23 (4): 454-461.

Shen, Y., Xu, Z., \& Sheng, Z. (2017). Ability of resveratrol to inhibit advanced glycation end product formation and carbohydrate-hydrolyzing enzyme activity, and to conjugate methylglyoxal. Food Chemistry, 216: 153160. doi: 10.1016/j.foodchem.2016.08.034.

Tang, L., Zhang, W., Zhao, H., \& Chen, Z. (2015). Tyrosinase inhibitor screening in traditional Chinese medicines by electrophoretically mediated microanalysis. Journal of Sparation Science, 38 (16): 2887 - 2893. doi: 10.1002/jssc.201500371.

Utami, A.W.A. (2014). Potensi ekstrak bakteri laut yang berasosiasi dengan spons sebagai antikanker dan antioksidan. [Tesis]. Bogor (ID): IPB.

Vauzour, D., Mateos, A.R., Corona, G., Concha, M.J.O, \& Spencer, J.P.E. (2010). Polyphenols and human health : prevention of disease and mechanisms of action. Nutrients, 2:1106-1131. doi:10.3390/ nu2111106.

Wu, B., Wu, X., Sun, M., \& Li, M. (2013). Two novel tyrosinase inhibitory sesquiterpenes induced by $\mathrm{CuCl}_{2}$ from a marine-derived fungus Pestalotiopsis sp. Z233. Marine Drugs, 11: 2713-2721. doi:10.3390/ md11082713.

Wuryanti. (2008). Pengaruh penambahan biotin pada medium pertumbuhan terhadap produksi sel Aspergillus niger. Berkala Ilmiah Biologi, 10 (42): 46-50.

Yoghiapiscessa, D., Batubara, I., \& Wahyudi, A.T. (2016). Antimicrobial and antioxidant activities of bacterial extracts from marine bacteria associated with sponge Stylotella sp. American Journal of Biochemistry and Biotechnology, 12 (1): 36-46. doi: 10.3844/ajbbsp.2016.36.46

Zahra U., Kartika, Y., Batubara, I., Darusman, L.K, \& Maddu, A. (2016). Short communication: Screening the potency of Zingiberaceae leaves as antioxidant and antiaging agent. Nusantara Bioscience, 8 (2): 221-225. 